First World War was in progress and within six months he joined the Army. He received a commission in the Buffs and saw service in Mesopotamia.

On returning to civilian life he speedily completed the actuarial examinations, becoming a Fellow of the Institute in 1922 . He spent the whole of his subsequent career with the Royal Exchange Assurance, being made Assistant Manager of the important Trustee and Executor Department at the end of 1928. On the retirement of T. F. Anderson in November 1937, O'Brien succeeded him as Actuary to the Royal Exchange, a position which he held until he himself retired in the summer of 1954.

He served the Institute in many ways. Between 1927 and 1936 he worked successively as a Tutor, an Assistant Examiner and an Examiner. He became Assistant Editor of the Journal in 1933 and Editor in 1935; he remained as Editor for ten years. He was a member of Council for an unbroken period of eleven years from 1934 onwards, an Honorary Secretary from 1938 to 1940 and a Vice-President from 1940 to 1943.

Jointly with T. F. Anderson he presented to the Institute two papers dealing with experiments with actuarial functions and Fourier's Series (J.I.A. 1928, 59, 256 and J.I.A. 1936, 67, 31). These experiments extended over a decade, and entailed building a machine which would calculate the constants for the graduation formulae.

Henry O'Brien was at heart a dedicated mathematician who maintained the highest degree of intellectual integrity in everything that he handled. With this, he was endowed with an innate sense of humour. Like some of his favourite characters (for he was a great admirer of the Gilbert and Sullivan operas) he loved an argument, and would often adopt a perverse attitude in order to stimulate discussion.

Though perhaps not one to suffer fools gladly, he was truly the kindest of men and he was greatly respected by all who knew him.

O. D. CUMMING

\title{
ARCHIBALD STEPHEN HOLNESS
}

ON 24 FEBR U AR Y 1972 Archibald Stephen Holness died at the home of his daughter, Dr M. E. Symonds, in New Jersey, U.S.A. Born in 1884, he was educated at Owen's School, Islington, a school which the writer remembers as being notable for its tuition in mathematics. Here, in almost every year, Archie was top of his mathematics class. He also took a keen interest in Physical Training which was then being supervised by a pioneer in Swedish Gymnastics.

In 1903 he started his insurance career with the Pelican and British Empire Life Company, which was merged with the Phoenix in 1908. Like so many of his generation his career was broken by the First World War. He joined the Beds. \& Herts. Infantry at the beginning of 1916 and was sent to India where he was engaged on Administration with the Army Headquarters at Simla. He rejoined the staff of the Phoenix in 1920 and thereafter served his company with great distinction, becoming Joint Assistant Actuary in 1929 and Investment Manager in 1935. He retired from the Phoenix in 1945.

His services to the Institute, of which he became a Fellow in 1913, were no less meritorious and he was certainly one of those who have upheld the Baconian motto to the full. He served as an Examiner 1921-27, and on the Council 1934-38 and 1940-47. He was honoured by election as Vice-President for the years 1943-46 during which time he chaired several committees, in particular the Finance Committee 1943-44 and the General Purposes Committee 1944-46.

On his retirement from the Phoenix he placed his extensive financial experience at the disposal of the Finance Committee of London University and also of the City Parochial Charities.

Only those who did not know him well enough could fail to be surprised at the great enthusiasm with which he entered into other activities divorced from business. He was a keen tennis player, a good bridge player and an outstanding chess player. In this he was a mainstay of the Phoenix Chess Club, and it is reputed that, when out rambling with his fellow Assistant Actuary, the late T. P. Thompson, the two of them would play chess without board and pieces. 
He was also a lover of music and at one time was a member of the Alexandra Palace Choir and in latter years his local church choir.

Archie Holness leaves two sons and two daughters to whom he had been a wonderful father. His wife predeceased him a year or two ago after many years of illness during which he gave her devoted care. Naturally at his advanced age few of his intimate friends remain to mourn his passing but there are still many of his younger colleagues, like the writer, who will always remember with affection and gratitude his friendship and the great assistance he gave to their training.

B. G. TURNER

\section{STANLEY FRANK ISAAC}

STANLEY ISAAC was born on 1 February 1906 and died on 12 April 1972 after a short illness. On leaving school in 1924, he joined the Atlas Assurance Company Limited and remained with that Company and the Royal Exchange Group, into which it was merged, throughout his entire business career. He was appointed Assistant Actuary of the Atlas in 1937, Deputy Actuary in 1944 and Actuary and Life Manager in 1946. In 1963, he became an Assistant General Manager of the Royal Exchange Group, which appointment he held until his retirement in 1967.

Isaac qualified as a Fellow of the Institute in 1928 at the early age of twenty-two and served the Institute in many capacities-Examiner 1936-38, Honorary Secretary 1951-53, Vice-President 1955-58 and Member of Council for seventeen years between 1946 and 1965. He was also editor of the Journal of the Students' Society in 1933-35 and Chairman of that Society in 194850. In 1945 he submitted, jointly with R. W. A. Fowler, a paper to the Institute on 'The Financial Investigation of Charitable Funds' (J.I.A. 1946, 72, 415). He was active in the affairs of the Life Offices' Association for many years and was its Chairman in 1961-62.

One of his great interests was the Insurance Charities and he was a member of the General Committee for over twenty years. In addition he was Honorary Actuary from 1945 until 1959 and President in 1960. Thereafter he became a Vice-President and in 1967, when in retirement, he was Chairman of a study group which examined in detail the affairs of the Charities and drew up proposals for reorganization.

In addition to activities connected with the profession and the insurance industry, Isaac devoted much time and energy to the affairs of the Congregational Church and of the British Home and Hospital for Incurables at Streatham. He was a Deacon and Treasurer of the Congregational Church at Caterham and served on the Finance Committee of the Congregational Church of England and Wales. In 1960 he was elected to the Board of the British Home, later becoming Chairman of the Finance Committee and Vice-Chairman of the Board and, in 1971, Chairman of the Buard.

Notwithstanding the demands of all these activities, he always found time to spend with his family, to whom he was devoted, and he took great pride in his home and, particularly, in his garden.

A man of strong convictions and principles with an immense capacity for hard work, application to detail and regard for strict accuracy and precision of expression, he successfully combined these qualities with kindness and a real understanding of the problems of his fellow men. By his example he was an inspiration to all with whom he came into contact and he will be remembered particularly for his selfless devotion to the interests of others in his business, professional and private life, epitomized in these words spoken at the service held in his memory, 'He was a good man, full of the Holy Spirit and of faith'.

O. V. HACKETT 